\title{
Where Did the Mullahs Go? Oral Histories from Rural Uzbekistan
}

\author{
Marianne Kamp \\ Laramie, WI
}

\begin{abstract}
Oral histories with elderly collective farmers in Uzbekistan, who recalled the establishment of their collective farms in the 1930s, depict the closing of village mosques and the disappearance of many rural mullahs. Anti-religious policies focused on Islamic institutions and paid functionaries; however, mullahs were left in many villages, and they continued to lead Islamic practices clandestinely. Religious leaders who had never been closely tied to Islamic institutions, such as otins (women religious leaders) were not targeted for arrest and removal. Our respondents remembered times when it was difficult to engage in any practice of Islam publicly, but they emphasized that nonetheless, community members fulfilled the ritual that they deemed most essential: the funeral prayer.
\end{abstract}

\section{Keywords}

Uzbekistan, collectivization, oral history, funeral prayer, mullah, otin, anti-religious policies

\section{Introduction}

Soviet policies were unfriendly to religion; this has been clear ever since the Bolsheviks came to power as a Marxist political party. Scholars have examined many of the ways that the Soviet state and Communist Party decimated religious institutions and tried to crush religious practices. However, evaluations of Soviet success in controlling Islam have varied. Islamic practice, like the practice of other religions, takes place both within and outside the built spaces that are dedicated to ritual, knowledge, and law. Practices such as family or group prayer that take 
place outside of buildings or spaces associated with religious organizations were and remain less vulnerable to government control than those that take place in institutional settings. ${ }^{1}$

This essay asks what was lost, and what remained of Islamic knowledge and practice in Uzbekistan, in the face of the Soviet state's attempt to destroy the social, economic, and ideological foundations of religion. Common knowledge of religious ideas and practices obviously could not be removed from the minds of living people who experienced life before Soviet repression, which began in 1927 and was most thorough in the 1930s. The state's mode for repression focused instead on closing buildings to religious functions, and arresting those who led those functions. Archival and published sources from the Soviet period, as well as scholarly studies, emphasize that those who occupied the position of teacher (domla, mullah, mudarris), judge $(q a z i)^{2}$, and imam were arrested, exiled, and executed, but oral histories suggest a less than total repression. A question about how many were arrested, and how many somehow managed to hide their identity has intrigued me since 1993, when I carried out an oral history interview with a Tatar woman in Tashkent. She showed me a photo of the Mufti of Ufa from the 1960s, and told me that this man had been her husband's domla in Kokand, Uzbekistan, in the early 1920s. I was surprised, and indicated that I thought all of the mullahs in Central Asia were arrested. Had this man come back from exile? No, she said; when he was no longer permitted

\footnotetext{
1) Scholarship on religion and atheism in the Soviet Union focused more fully on Russian Orthodoxy than on other religions. Recent work exploring Soviet policies on Islam in Central Asia, and their results, include Yaacov Roi, Islam in the Soviet Union (New York: Columbia University Press, 2000); Shoshana Keller, To Moscow, Not Mecca: the Soviet campaign against Islam in Central Asia, 1917-1941 (Westport, Conn.: Praeger, 2001); and Islam in Politics in Russia and Central Asia (early eighteenth to late twentieth centuries), ed. S. Dudoignon, K. Hisao (London: Kegan Paul, 2001). The observation that the state could suppress institutions, but was less successful in suppressing unofficial practice of religion, or "popular" religion, has been made throughout the literature on Soviet religion in general, and Soviet Islam in particular.

2) This paper follows Uzbek conventions in naming, spelling, and pronouncing Islamic religious terms. Domla comes from Persian domullah; it is used both as an equivalent of mullah and specifically to mean teacher. Uzbeks render qadi as qazi. Uzbek names and terms are in their present day Uzbek latin alphabet form, rather than in forms of transliteration based on either the Cyrillic or Arabic alphabets.
} 
to be a religious teacher, he became a bookkeeper, and then during or after WWII he returned to his religious profession. ${ }^{3}$

Archives provide records of events_ of happenings that were observed and deemed significant enough to record. The Soviet archives provide surprisingly few specific records for arrests of mullahs, but more extensive records on mosque closures, and forms with aggregated figures of religious personnel who were arrested and exiled. When mullahs took their fate into their own hands, by moving, taking up another line of work, or hiding, that was a non-event: unknowable, and unrecorded, unless and until the mullah and his actions were uncovered or "unmasked". ${ }^{4}$

Elderly collective farmers across Uzbekistan, interviewed for an oral history project, remembered the efforts to halt overt practice of Islam in their own communities in the 1930s, but presented a wide variety of stories about what became of their local mullah or domla. Some recalled that the mullahs fled, others said that they were arrested and exiled or executed, and others indicated that they stayed and continued their practices secretly. Archival records from the 1920s reveal that the majority of Muslim religious leaders were arrested and removed from their communities, while records from the 1950s and later indicate the persistence of Islamic practice throughout the Soviet Union, led by village mullahs and imams. ${ }^{5}$ A comparison of accounts of elderly farmers who lived through the 1930 s with archival sources from that period, tends to confirm that the Soviet state's effort to suppress Islamic institutions was harsh and far-reaching in the 1930s. Although archival records document a severe reduction in the numbers of mullahs through arrest and exile, oral histories suggest that many still remained in rural villages, and collective farmers continued to turn to them for religious leadership.

The materials for this paper are drawn from an oral history project interviewing elderly rural Uzbeks who experienced collectivization of

\footnotetext{
3) Aisha B., b. 1909 Ufa, interviewed in Tashkent by Marianne Kamp, 1993.

4) Sheila Fitzpatrick discusses some of the guises that Soviets used to hide or alter their class identity, and Communist concerns with unmasking these "imposters", in Tear Off the Masks: Identity and Imposture in Twentieth Century Russia (Princeton: Princeton University Press, 2005).

5) Keller, To Moscow, Not Mecca, chap. 5 and 7; Roi, Islam in the Soviet Union, chap. 5.
} 
agriculture. The interviews were undertaken between 2001 and 2004, with respondents who were born between 1905 and the early 1920s. These 118 interviews were carried out in rural communities in seven provinces of Uzbekistan: Toshkent, Namang'on, Farg'ona, Qashqa Daryo, Xorazm, Buxoro, and Navoiy. ${ }^{6}$ Interviewees included ninety men and thirty one women; several interviews involved two respondents. They were born in rural communities and lived on land that was collectivized between 1929 and the mid 1930s. The interviews concerned the processes of collectivization, and asked only one specific question related to religion, which was about whether there was a mosque in the village, with a follow-up question in many cases about whether the interviewee recited prayers. Otherwise, comments about religion emerged because the elderly collective farmers brought up the topic themselves, and interviewers followed up with additional questions.

This article focuses on four topics that recur in the collective farmers' stories: what became of mosques and mullahs in their villages; whether the mullahs fled rural communities on their own, or were arrested, or remained; the roles some villagers played in repressing Islam; and the ways that Islam continued to be practiced in the villages. The themes that emerge in these oral histories suggest that ordinary kolkhoz members were strongly discouraged from practicing Islam during the 1930s, and that the institutional bases for Islamic practice were severely damaged. Many of these elderly collective farmers explained that they were believing, practicing Muslims, and that during the Soviet period they

6) "Collectivization in Uzbekistan: Oral Histories", primary investigators, Marianne Kamp, Russell Zanca, and Elyor Karimov. Funded by a National Council of Eurasian and Eastern European Research (NCEEER) contract, 2002-2004; also funded by the University of Wyoming's Basic Research Grant, and Faculty Grant-in-Aid, 2001 and 2003; and by an IREX Short Term Research Grant in 2002. The project carried out 118 oral history interviews with elderly kolkhoz members between 2001 and 2004. Most of the interviews were undertaken by the Yosh Olimlar Jamiyati (Young Scholars Society), a research group associated with the Uzbekistan Academy of Sciences, and headed by Dr. Elyor Karimov. Kamp and Zanca conducted about 15\% of the interviews; interviewers from Yosh Olimlar conducted about $85 \%$ of interviews. Interviews were in Uzbek (with the exception of 3 in Tajik) and Uzbek transcriptions are available. Most informants were male, born between 1899 and 1925, and came from dehqon (farmer) families, though some left the collective farm after WWII. 
had continued with some Islamic practices, including prayer and fasting. When one compares the ways that elderly collective farmers talked about the mullahs in their communities with the ways that they spoke of quloqs (kulaks) ${ }^{7}$ who were dispossessed, there are incongruities that suggest that our respondents were more habituated to silence about religion than about other topics: they named the names of the quloqs, but perhaps were more committed to keeping secret the names of the mullahs. Although mosques were closed, many reported that they learned recitation from family members, that villagers still performed the prayers, and that in some places, mullahs remained or returned.

\section{Background: Religion and Collectivization of Agriculture in Uzbekistan}

The Russian Empire's general practice was to grant formal recognition to specific religions (Orthodox Christianity, Catholic Christianity, some Protestant Christian sects, Judaism, Islam, and Buddhism) and to exercise some oversight of their religious institutions (houses of worship, courts, institutions of learning). Islam in Russia was organized through formal structures, the Muslim Spiritual Administrations, but after seizing control of Turkestan in the 1860s, Russian governors specifically excluded Turkistan's Muslims from association with the Orenburg Spiritual Administration. ${ }^{8}$ Nonetheless, the Imperial administration in Turkestan collected information about religious institutions, compiled a registry of madrasas that included lists of personnel, income and number of students, and created procedures for the election of Sharia

\footnotetext{
7) Kulak is a Russian word meaning "fist". Russian peasants living on traditional communes used the term to refer to peasants who had become wealthier than most members of the commune, and the Communist Party carried out class warfare in the Russian countryside by getting poor peasants to turn against kulaks, and then removing the kulaks through arrest and exile. When the term kulak came into the Uzbek language, it was rendered "quloq", which means "ear"; in other words, the term itself had no traditional meaning to Uzbeks, and it was used interchangeably with boi, meaning wealthy landowner. Throughout this paper I use the Uzbek spelling, quloq, rather than the more familiar Russian spelling, kulak.

8) Adeeb Khalid, The Politics of Muslim Cultural Reform: Jadidism in Central Asia (Berkeley: University of California, 1998), 54.
} 
judges ( $q a z i)$ who then were recognized as functionaries of the Russian imperial state. ${ }^{9}$ Interestingly, some Turkestani Muslim leaders sought more organization and administration: in 1905 they began petitioning for the formation of a "spiritual assembly", following the model found elsewhere in the Russian Empire. ${ }^{10}$

Following the October Revolution in 1917, the Soviet government permitted Muslim leaders to create organizations, and then, starting in 1927, repressed Islamic institutions and seized their properties. ${ }^{11}$ The Soviet administration in Central Asia began undermining Islam's institutional bases in 1918, with the creation of new "people's courts" that would compete with Muslim courts, and with efforts to confiscate waqfs. However, Soviet leaders sought accommodation with Islamic institutions in the early 1920s, by allowing the ulama to organize themselves locally in bodies named mabkama-yi shar'iyya, by including Muslim religious scholars in projects for a new code of civil law, rescinding the directive on waqf confiscation and instead directing waqf revenues toward the support of education, and allowing Muslim courts, religious schools, and mosques to continue operating. ${ }^{12}$ These forms of accommodation gave state organs modes to gather more information about personnel whose livelihoods were based on Islamic institutions: the domla who taught children in a maktab, the mudarris who instructed students at the madrasa, the qazi who judged in the Muslim court. Others who exercised forms of communal religious leadership, such as the heads of Sufi orders, or keepers of shrines, were not drawn into the purview of the state.

The Soviets leveled a severe attack on the Russian Orthodox Church in 1922, arresting priests, closing churches, and seizing church-owned wealth. A similar shift in policy against Islam and Islamic institutions

9) V. V. Bartol'd, "Istoriia kul'turnoi zhizni Turkestana", chap. 7, "Shkoly", Sochineniie, [Collected Works] vol. 2, part 1, 313-318; and chap. 10, "Tuzemtsy i russkaia vlast'," idem., 359f., (Moskva: Izdatel'stvo vostochnoi literatury, 1963 [1927]). In Xorazm and Buxoro, which became Russian protectorates rather than Russian colonial territories, judges continued to be functionaries in service of the khan and emir.

10) Khalid, Politics of Muslim Cultural Reform, 230.

11) Adeeb Khalid, Islam after Communism: Religion and Politics in Central Asia (Berkeley: University of California Press, 2007), 61. Keller, To Moscow, Not Mecca, $61 \mathrm{ff}$.

12) Keller, To Moscow, Not Mecca, chap. 1. 
began in 1927. This attack on Islamic institutions coincided with the Hujum, which was a campaign to change women's lives in Central Asia by destroying what Communist leaders saw as backward customs, such as veiling. It also coincided with land reform efforts in three provinces of Uzbekistan (Syr Daryo, Farg'ona, and Samarqand). The attack on Islam focused both on institutional spaces and on personnel: government and Party officials closed mosques, madrasas, maktabs, Muslim courts, seized waqf properties for land redistribution, and arrested mullahs, qazis, and other religious professionals.

In the 1920s, Soviet agricultural policy wavered between strategies designed to increase productivity, such as allowing markets for farm products, and strategies designed to enhance government control over the countryside, such as collectivizing agriculture. Land tenure in Soviet Uzbekistan took a variety of forms. Land in Xorazm, Syr Daryo, Farg'ona, and Samarqand provinces was individually owned. Smallholders (dehqon) generally owned less than ten hectares. Those who owned relatively large holdings were called boi (rich); a boi, in Soviet class-based terminology, was someone who had more land than his family could farm, and who hired laborers to plow his irrigated fields and to herd his livestock. In Qashqa Daryo and Surxon Daryo provinces, where herding and dry land farming predominated, there were bois who had large holdings, but there were also extended families that shared large holdings, and rural communities that held land in common. In Uzbekistan, from 1925 until 1929, the state pursued land reform, rather than collectivization. Land reform entailed seizing large land holdings from the bois and redistributing them to small holders, or to landless farm workers (mardikor or batrak) ${ }^{13}$.

The Communist Party regarded the bois as obstacles to Party authority in rural communities, and in land reform, it sought to pit the interests of the rural poor against the interests of the rural rich. Lists of bois were compiled, and their lands were surveyed, seized, and parceled out. Bois who appeared to challenge this policy were arrested and exiled to other parts of Uzbekistan, or to more distant places in the Soviet Union.

\footnotetext{
13) Uzbek oral histories use Uzbek terms for wealthy landowner (boi), and for small-holding farmer (dehqon), but for farm laborer they use both Uzbek terms (mardikor, nimcha) and the Russian term (batrak).
} 
The boi was not simply a large landowner; he usually also played a leading social role in the village, distributing charity to the poor and providing resources to support the mullahs. The Party viewed rural mullahs as the ideological supporters or clients of the bois, and in 1927, started to arrest mullahs as well. In sum, before collectivization of agriculture formally began, the Communist Party in Uzbekistan was already well on the way to removing traditional leaders - the bois and the mullahsfrom Uzbekistan's rural communities.

State efforts to extirpate religious institutions gained impetus when the mass collectivization of agriculture began in November $1929 .{ }^{14} \mathrm{Col}-$ lectivization brought rural communities throughout Uzbekistan under direct Soviet administration, expanding connections between small villages and regional Party organizations. Party members who organized kolkhozes (collective farms) also instigated mosque closings and the arrest of village religious leaders. ${ }^{15}$ In Uzbekistan, activists from the Communist Party brought farmers together in community meetings, and told them that if they joined their lands together and worked as a collective, they would obtain loans, seed, and equipment from the state, and would be able to improve their lives. Then community members were asked, or forced, to sign up for the collective farm. Bois were not

\footnotetext{
14) The timeline and policies shaping collectivization in Uzbekistan were the same as in central parts of the Soviet Union, a topic about which there are numerous scholarly works, including Robert Davies, The Socialist Offensive: the collectivization of Soviet Agriculture, 1929-1930, (Cambridge: Harvard University Press, 1980), and The Soviet Collective Farm, 1929-1930, (Cambridge: Harvard University Press, 1980); and Sheila Fitzpatrick, Stalin's Peasants: Resistance and Survival in the Russian Village after Collectivization (New York: Oxford University Press, 1993). Thorough accounts of collectivization in Uzbekistan, based on archival research with a Soviet lens, are found in works by the historian Rahima Aminova: Agrarnye preobrazovaniia v Uzbekistane nakanune sploshnoi kollektivizatsii (19251929) (Tashkent: Iz. Fan Uzbekskoi SSR, 1969); Osushchestvlenie kollektivizatsii v Uzbekistane (1929-1932 gg.) (Tashkent: Iz. Fan Uzbekskoi SSR, 1977). Recently several collections of archival documents on collectivization have been published: Tragediia sovetskoi derevni: kollektivizatsiia i raskulachivanie. Dokumenty i materialy v 5 tomakh, 1927-1939, ed. V. Danilov, R. Manning, L. Viola (Moskva: Rossiiskaia polit. entsiklopediia, 19992006). Tragediia sredneaziatskogo kishlaka: kollektivizatsiia, raskulachivanie, ssylka, 19291955 gg. Dokumenty i materialy, ed. D. Alimova (Tashkent: Sharq, 2006).

15) Keller, To Moscow, Not Mecca, chap. 5; Marianne Kamp, The New Woman in Uzbekistan: Islam, Modernity, and Unveiling under Communism (Seattle: University of Washington Press, 2006), 189-193.
} 
permitted to join collective farms. Efforts for collectivization continued through 1935, by which time the vast majority of Uzbek farmers and lands were in kolkhozes. Throughout that period, the state placed everincreasing pressure on wealthy or even mildly prosperous farmers who remained outside the kolkhozes. These bois were designated "quloqs", and were subjected to "dekulakization", meaning dispossession, arrest, exile, or even a death sentence. The local kolkhoz could name hold-outs, or even kolkhoz members who had retained some of their own property, as quloqs, search their homes, seize their lands and goods, and have them arrested and shot or exiled.

At the time of collectivization, most rural communities had at least one mosque, and many also had holy sites, usually the tomb of a member of a saintly lineage. Religious leaders in rural communities might include: a male imam who was formally educated in a madrasa and who led Friday prayers; a male mullah or domla who taught boys in a maktab and who led prayers and gave religious guidance and instruction to community members; a male eshon who was associated with a local tomb or place of pilgrimage; an otin (woman religious teacher) who taught girls and led women's religious celebrations; and possibly leaders associated with shrines or Sufi orders. A religious leader might also be a land owner or have other sources of income besides that generated by religious activities. Under land reform, collectivization, and dekulakization, village activists arrested religious leaders and dispossessed them if they fit the ever-changing criteria for quloq, and also if they were seen as political supporters of the bois and quloqs. However, evidence from interviews suggests that many mullahs remained in the villages and became kolkhoz members.

\section{Common Stories: Mosque Closings and Mullahs Who Stayed}

Mullahs were ephemeral; mosques were not. Mullahs could "disappear", but Party activists eliminated Islam's built spaces in villages, by putting mosques to new use as storehouses, or by tearing them down. Among elderly collective farmers, the most common recollection about religion is that in the 1930s, the village mosque was closed. 
Zaynab H.’s account was typical:

We had an old mosque on the kolkhoz; it was always there. But people did not go. There were some years when we had to recite the funeral prayers in secret. We had a kind of mullah. He was not dekulakized. He was the kind that recited the funeral prayer (janoza), secretly. And then he died. ${ }^{16}$

Accounts in which mosques closed, but mullahs continued to serve their communities in secret ways, were frequent. Nurmurod H., who grew up near G'ijduvon in Buxoro province, had similar recollections about the village mosque. He said:

On the kolkhoz there was a mosque, but it was not large, and it was not open. People went, but gradually fewer and fewer. When the kolkhoz began, there was a mosque, and the mullah entered the kolkhoz without any restrictions at that time. The mosque was in the center of the village, a separate village. Gradually it was destroyed and disappeared. On that land they built some communal building, a teahouse or a cafeteria. Eventually the mullah passed away. Basically mullahs were no longer mullahs after collectivization. Most of them left. ${ }^{17}$

Yoqubjon B., from a mountain village near Marg'ilon, noted that the disappearance of buildings dedicated to religious purposes did not mean that their personnel also disappeared: "The old style school continued but gradually disappeared. It went on in a secret place where [Sufi] brotherhoods (jamoat) met. The domlas there were just simple people who happened to become domlas. They were not killed or anything." 18 The religious teachers were still in his village, and continued teaching,

16) Zaynab X., b. 1922 Qashqa Daryo province, QD6, transcript, 5. Janoza (Uzbek) for janazza (Arabic). Following the principles of oral history, this paper uses the actual names of respondents. Oral history interviews people in order to listen to individual stories, and obtains interviewee permission to use those stories, attributing them to their real "authors". However, this paper refrains from identifying respondents using last names or specific village names. See the Oral History Association's "Principles and Best Practices", http:// www.oralhistory.org/do-oral-history/principles-and-practices/, adopted October 2009, for a fuller understanding of the ethics of oral history, and why oral historians are interested in the voices of identified subjects, as opposed to anonymous subjects.

17) Nurmurod H., b. 1921 G'ijduvon, Buxoro transcript 1, 2.

18) Yoqubjon B., b. 1919 Vodil, Farg'ona transcript 11, 3. 
but this may not have been widely known, since they were no longer identified with a built space, the school or the mosque.

In a village near Namang'on, Yo'ldashev explained one of the means by which mullahs survived:

There was a domla, but back then no one was interested in the mosque; there was no mosque. And if one were to recite, everyone would laugh. And if someone still knew it they would be locked up and taken away. Before collectivization, everyone could [practice] if he wanted to. In Soviet times, after collectivization, no one was religious at all, there was no namoz [five daily prayers] at all, even if someone died [...] People were deprived of knowledge. But the old domlas still knew and recited. Not all of the domlas were arrested and taken away leaving their children. Those old domlas did not work on the kolkhoz; they lived on what people brought them to eat. ${ }^{19}$

Comparison of these accounts shows variation from kolkhoz to kolkhoz: some permitted mullahs to join, while in others, mullahs who remained led a precarious existence.

Although many respondents reported that mullahs remained in their village, they did not identify them by name. Mullahs who remained were named only in accounts told by their family members. Xorazm resident Sidiq U. was the son of an oxun (akhund) ${ }^{20}$ who had served as a qazi in the city of Xiva. After the Soviets took over and began repressing Islamic institutions, "He returned to his home village, and they did not tell anyone. He could not practice his profession any longer. He had five or six tanobs of land [a small parcel] and he farmed it." When asked whether the village people reported his father, Sidiq responded that his father was called in for questioning: "Tell the truth, were you formerly an oxun?' They just killed those who did not tell the truth. He said, 'I was a xo'ja, an oxun'; he didn't hide it. They killed everyone who tried to conceal [their background]." ${ }^{21}$ Knowing that most similar religious leaders were arrested, Sidiq tried to make sense of his father's

\footnotetext{
19) Y'oldashev [given name missing from transcript], b. 1923, Namang'on province transcript 1, 23.

20) Sidiq explained oxun (akhund) as an educated man with a degree higher than that of a mufti.

21) Sidiq U., b. 1907 Xiva city, Xorazm transcript 3, 1, 10.
} 
survival, attributing it to his honesty, and by extension, to some logic or justice in the state's repression of religion.

Abdulla S., from another village in Xorazm province, said that some of the mullahs fled, and some were arrested, but he named a relative who continued to serve as a religious leader:

We had a relative named Masharip Oxun. He was the director of the madrasa, he was a mudarris. So he studied there [in Xiva] and reached the degree of oxun. Then he turned up there in the city and then they started killing the mullahs, and he came here and became the imam, in his own village [...] in 1930 [...] The mosque had not yet been destroyed. They did not destroy ours, but simply put a stop to the mullahs [...] A person could recite namoz alone, but if one recited to teach others, they were sentenced to three years imprisonment. The elderly could not teach; they could only recite alone. They couldn't teach the young, or they would be called to account. Masharip Oxun stayed here for a year and then later he was made an imam. He continued as imam and died at age $94 .{ }^{22}$

Soviet ethnographers working in rural Uzbekistan in the 1950s and 1960 found numerous village mullahs who led prayer and life-cycle rituals; it seems reasonable to assume that some of them had been there all along, as these oral histories suggest, while others had returned from imprisonment or exile. Archival records show that some of these mullahs petitioned for the re-opening of mosques, and for official appointment as mullah. Whether their petitions were accepted or rejected was probably related both to swings in the post-Stalin Soviet leadership's concern about religious practice, and to the attitude of local officials.

\section{Common Stories: Harsh Repression and the Funeral Prayers}

In the above accounts, Yo'ldashev mentioned a time when repression was so severe that kolkhoz members could not even fulfill funeral prayers, and Abudulla S. pointed out that believers could recite prayers at home, but not in a communal form. Local officials, who generally were Uzbeks who had joined the Communist Party or took positions

22) Abdulla S., b. 1921 Ko'shko'pir district, Xorazm transcript 12, 9 f. 
in their village soviet, often actively prevented gatherings for prayer and fasting for Ramadan. Rustam M., from a Navoiy village, said:

On the kolkhoz, on religious holidays, at least ten or fifteen militia would be out guarding. No one was allowed to recite in the mosque [...] All the mosques were closed, and a person might recite alone at home, but not do namoz..$^{23}$

Oqqo'zi B., born in Qashqa Daryo province, said:

There were no mosques, those were closed in 1938-1940. People would hide to pray, perhaps in a cluster of poplars, but then there was an order that people should not pray at all. That was very hard. People did still recite funeral prayers $\left(\right.$ janoza) ${ }^{24}$

Qarol M.'s story focused on repression and fear. Unlike most other accounts, he named one of the many mullahs who was arrested:

People who were named parasites were imprisoned, and that threw fear into the educated people, the mullo-eshons. ${ }^{25}$ For example, Dillaxon Eshonbobo was the most educated person, he was imprisoned, and he did not return $[\ldots]$ he died in prison. There was a very small mosque built here $[\ldots]$ but no one was allowed to enter it in that period. Everyone was scared off, but later, after the kolkhoz was founded, and after the war, then a few old men started to go there quietly [...] At that time they always recited janoza but they couldn't do it early in the morning, and they did it always looking over their shoulders. The mullah would recite, but no one felt free to recite, and there was no freedom for the most educated person. ${ }^{26}$

Xurram X. told a similar story about his village:

There was always a mosque in the village, but at that time, people did not go there to recite. People were told they were not allowed in there, and the

\footnotetext{
23) Rustam M., b. 1912, Navoiy province transcript 8, 16.

24) Oqqo'zi B., b. 1916 or 1922 (unclear documentation) Qashqa Daryo, QD interview 5, transcript, 3 .

25) Eshon, or ishan, is a title given to the leader of local Sufi group, or to a mullah who has earned a high reputation for learning.

26) Qarol M., b. 1922 Qashqa Daryo province, QD 11, transcript, 3.
} 
mosque was made into a storehouse. People said the prayers for the dead. If you don't say janoza, you can't bury someone, after all, so they would recite, even if in secret. The village had a mullah. There was no place that a mullah would be left in peace, so he did this in secret. ${ }^{27}$

Our interviewers asked specific questions about mosques closing, and whether people recited namoz (namazz, the five daily prayers). Frequently, interview subjects responded to this by mentioning janoza, either to point out that even in the most difficult times, they still performed the funeral prayers, or to stress that repression even prevented this final dignity. One interpretation of this might be that our respondents were all elderly, and hence death and janoza were rather pressing issues for them. Alternatively, it may speak to the specific ways that the severe reduction of the possibility of Islamic practice in Uzbek daily life set priorities for what believers felt to be the most essential elements. Although they did not do five daily prayers, or fast through Ramadan, they would still recite janoza in order to be able to bury the dead properly. ${ }^{28}$ Their accounts echo Kyrgyz author Chingiz Aitmatov's theme in the novel The Day Lasts Longer than a Hundred Years, where Burannyi Yedigei's primary religious concern is that funeral prayers be said for Kazangap, and that he be properly buried. ${ }^{29}$ Other practices could be repressed or ignored, but the inevitability of death necessitated taking some risks to fulfill Islamic norms.

\footnotetext{
27) Xurram X., b. 1920 Qashqa Daryo province, QD 8, transcript, 4.

28) Another possibility, suggested by Ingeborg Baldauf, is that janoza was a topic of debate at the time of these interviews; this seems somewhat likely because janoza comments were concentrated in Qashqa Daryo interviews carried out late in 2003. Both in the Soviet period and since independence, there are debates about right practice, which usually pit madrasa-trained ulama against those who follow traditional practices. These debates focus heavily on funerary and shrine rituals. See Bakhtiyar Babadjanov, "From Colonization to Bolshevization: Some Political and Legislative Aspects of Molding a 'Soviet Islam' in Central Asia”, Central Asian Law: An Historical Overview, ed. W. Johnson, I. Popova (Lawrence, Kan.: University of Kansas, Society for Asian Legal History, 2004), 153-171. However, respondents from Namang'on and Navoiy, interviewed in 2001 and 2002, also mentioned janoza.

29) Chingiz Aitmatov, I dol'she veka dlitsia den' (Frunze: Kyrgyzstan 1981; English trans. John French, Bloomington: Indiana University Press, 1983).
} 


\section{Common Stories: The Mullahs Were "Made quloqs" or They "Left"}

The Communist Party linked religious leaders, like mullahs and imams, to the village bois, but ordinary perceptions of oppressors differed from the Party line. Party activists generally put two terms, boi and mullah, side by side in their discourse; both were oppressors, and both were the target of dispossession, arrest, and exile. Ordinary kolkhoz members who spoke to us in the early 2000s about their own experience of collectivization tended to agree with Party definitions of who is a $b o i$ : the boi had owned significant land and exploited landless farm laborers; on this basis the kolkhoz could name him a quloq, and have him arrested. Oral history respondents quibbled only over whether specific people had deserved the quloq label. In contrast to Party discourse, only a few respondents put "mullah" in the same category as quloq or boi. ${ }^{30}$ In the above accounts, respondents sometimes noted that certain mullahs who stayed were ordinary people who could enter the kolkhoz.

In some villages, religious leaders were owners of large amounts of land, and were dispossessed along with the rest of the quloqs. Dekulakization (removing the wealthy landowners) was a public matter, involving meetings, denunciations, and participation by the mobilized members of the nascent kolkhozes. Abduqodir P., from Parkent, said:

At the time, the rich included some eshons, like Sadriddin eshon, who had a lot of land and water. The government seized all of it and sent him into exile [...] They arrested people for being domlas, and they exiled the richer ones who had land. ${ }^{31}$

Tojivoy D., of Parkent district, remembered the specific measures that the state used to determine who was a quloq. He said that his own father met those criteria, but he had been able to avoid dispossession because of the ways he had cultivated relationships in the village. In Tojivoy's understanding, the domla was dispossessed not because he was a religious leader, but because he met the criteria for quloq. As he put it:

\footnotetext{
30) Marianne Kamp, "Seven Blind Men: Memories of Collectivization and Class in Uzbekistan”, unpublished conference paper, European Society for Central Asian Studies Conference, Middle East Technical University, Ankara, Turkey, September 2007.

31) Abduqodir P., b. 1916 Parkent district, Tashkent transcript 16, 5.
} 
Quloqs at that time were determined by their income, and they were driven out, imprisoned, with their families [...] In this village Abduvaliboy and Hayitboy entered the ranks of quloq. There were four or five. One of them, our domla G'olibberdi, was taken away at night, with his family. ${ }^{32}$

The state launched the first major crackdown on Islam in 1927, well before collectivization and the accompanying dekulakization campaign started. ${ }^{33}$ Shoshana Keller notes that in 1927, when the Party decided to restrict Islamic practice, there were very few explicit directives about how to treat Muslim religious leaders. In several cases there were orders to arrest imams or mullahs, and more specifically, to do so at night, so as to reduce community disturbance. The lack of specific orders or other records of arrest for mullahs and other religious leaders makes it difficult to know how common this was. ${ }^{34}$ But several of the interview respondents remembered incidents of night or secret arrests of mullahs in their villages. These cases were memorable enough, and perhaps the stories were repeated enough within families, that respondents sometimes remembered these mullahs by name. Thus Mahkam T., who grew up near Marg'ilon, said:

After Soviet government was established they got rid of the rich and the mullahs. For example, here in Vodil there was a Katta Qori aka who had an older brother No'mon Qori ${ }^{35}$ [...] And one evening he disappeared, and was sent off. Our grandfather's paternal uncle Jamol Mahsim also, one evening. He had a son, Shamsiddin. He was sitting in front of Qori aka's mosque one evening when he was sent off. Where he went, wound up, whether he was imprisoned or died, we don't know. He did not return. ${ }^{36}$

Nemat B., from G'ijduvon remembered that the mullahs disappeared from the village during dekulaization:

32) Tojivoy D., b. 1917 Parkent district, Tashkent transcript 2, 6.

33) However, Keller presents evidence that in 1927, the crackdown was heavier on urban clergy, who were reported as leaving cities and going to rural communities. If this was the case, villages may have seen rising, rather than falling, numbers of clergy in 1927. Keller, To Moscow, Not Mecca, 67-71.

34) Keller, To Moscow, Not Mecca, 122.

35) Qori is the title given to one who memorizes and recites the Qur'an.

36) Mahkam T., b. 1921, Marg'ilon 12 (Vodil), 3f. 
The mullahs left. A lot of them were exiled. Five or six from our village were exiled. They were poor, but they were exiled anyway. They said, you are so and so's son. The activists made this happen, people who worked for the Party or the Komsomol. Their families stayed; people did not treat them badly. They entered the kolkhoz and worked. They did sometimes point them out as enemies. The NKVD carried out the exiles; they came at night. ${ }^{37}$

Arrests of mullahs and imams began in earnest in the late 1920s, while dekulakization was associated with the formation of collective farms, and in most regions of Uzbekistan continued through in mid-1930s. The arrest of mullahs and dekulakization ran together in the minds of the elderly, for several reasons. In many cases, people who were village domlas were also land owners, and were targeted for arrest or exile, at least ostensibly, not because of their religious role but as quloqs.

Among the respondents, even those whose own families were named as quloqs tended to express the idea that removing quloqs was right, but occasionally dekulakization rounded up the wrong people. Faizulla H., born in 1905 in Qashqa Daryo, was unusual in expressing outrage at dekulakization. Faizulla remembered the mullahs from his village who were dispossessed as quloqs:

We worked, and this person was rich and this one was poor. But no one was really oppressed. In Maymonoq there were no oppressor-bois, but one day I counted up, and 54 people were wrongly arrested. There was Abdullaboy, and someone called Mullah Kenja; they were sentenced to two years. They disappeared from this village without a trace. They were arrested because, it was said, they oppressed us, but they hadn't oppressed us at all [...] At that time there was the NKVD and the militia, and the regional committee; when there was a meeting, people would come from the regional commitee. Among those who were dekulakized, Abdullaboy did not have any livestock; Mullah Kenja had 100 or 200 sheep and was himself a dehqon; he was left with nothing. Mullah Ubaidulla and Arabxon were both batraks. The state took their land. ${ }^{38}$

37) Nemat B., b. 1916 G'ijduvon, Buxoro 2, 5. NKVD is an acronym for the secret police. The organization was first known as the Cheka, then the OGPU, then NKVD, and then KGB. In the early 1930s they were empowered to carry out swift arrest without oversight from the local Party organs.

38) Faizulla H., b. 1905, QD 17, 2. A batrak was a farm-laborer; Faizulla's account seems to indicate that at the time of their arrest, these mullahs were making a living as farm workers, though they also owned a little land that the state took. 
In Faizullah H.'s recollection, these two mullahs, Kenja and Ubaidulla, were arrested as quloqs —in his opinion, wrongly_-rather than under any accusation associated with their status as religious functionaries. The arrests in this case had a public context: the kolkhoz held meetings and authorities attended in order to carry out arrests. These were not stealthy, nighttime disappearances; they instead were events that were widely witnessed and would be remembered.

Hamid U., from Marg'ilon, had become a local historian, and mixed what he knew from his research with what he remembered from childhood about the arrest of mullahs:

They turned mosques into pharmacies and storehouses. And in Marg'ilon our activists turned mosques into cafeterias. I think the struggle against the mosque was a wrong policy. Now there are 70 or 80 mosques in Marg'ilon. One hundred of Marg'ilon's domlas were arrested, imprisoned, and not one left alive [...] People who were educated or who had books in their homes were sought out and arrested. The Troikas were really bad. ${ }^{39}$ Three or four people on a Troika could declare that a person was black or white. Then if Stalin had not reined in that policy, I don't know what all Uzbeks would have done. The Troikas were important for the policy of dekulakization and finding enemies of the people. Whoever it was, they would take them. They would come at night and take them away, leaving their children crying. ${ }^{40}$

Although some community members witnessed the secret police arresting mullahs and quloqs, most of them only mentioned the results: the sudden disappearance of the mullahs from their communities. But not everyone thought that the mullahs had been arrested. Some stated that the mullahs "left".

Many respondents recalled the names of wealthy land owners who were arrested and sent into exile. But they were far less likely to name mullahs. Their stories of mullahs "leaving" the village lack detail. Respondents identified their own relatives who remained in their villages as mullahs, and they remembered names of some of those who were arrested as quloqs. Otherwise, both mullahs who stayed, and those who "left", remained anonymous. The anonymity of the mullahs

\footnotetext{
39) A troika was an extraordinary commission, comprised of three members, sent by the Party to carry out swift arrest, investigation, and sentencing.

40) Hamid U., b. 1922, Marg'ilon 1, $10 \mathrm{f}$.
} 
contrasts rather strikingly with other aspects of most of these oral history accounts, which are replete with names of the bois, the quloqs, and the kolkhoz leaders.

Bekmurod Sh., born in Qashqa Daryo in 1907, reported that the village mosque was closed, but attributed the disappearance of mullahs from his village to flight rather than to arrest:

In the 1930s there were mosques, but then they were closed entirely in 1930, 1931. It was impossible to go to the mosque to pray. They were all turned into storehouses, or opened up to other purposes. The mullahs fled; most of them were quloqs, and some of them fled to other villages. ${ }^{41}$

Ahmad U., of G'ijduvon, attributed the disappearance of the mullahs both to force and to flight:

When the Soviets came they forbade the mosque, then went in and threw out the domlas. Then they did not let people go to mosque, and it lay in ruins. In our village there was a mosque with several mullahs. Some of them fled on their own, while others were exiled.42

Halil F.'s account contains two versions of what happened to village Islam, both destruction and survival. He was older than other respondents, born in 1905, and his account included specific names of villagers who were dispossessed:

There were mosques in the village, but all of them were torn down. From here to Qarshi there was not one mosque. That was in 1937-38. People were not allowed to recite namoz. For example, during Ruza (Ramadan), six or seven militia would come and find the place where people were praying and would not let them pray; they would prevent four people from forming a

41) Bekmurod Sh., b. 1907, QD 12, transcript, 6.

42) Ahmad U., b. 1921 G'ijduvon, Buxoro 3, 7. In most interviews, we asked who had carried out the organizing of the kolkhoz. Most respondents identified the organizers either as local Uzbeks, or as Uzbeks from the regional center. Sometimes, though, they attributed these actions to Russians, Soviets, or Bolsheviks, with an implication that the organizers were foreign or distant people. Some regarded the formation of the kolkhoz as "when the government came". In many districts, this was a logical perception. Throughout the 1920s, many rural regions had almost no Soviet government presence, and land reform and collectivization began with the organization of village soviets (governing councils). 
group, and would tell them to move out to the fields. They weren't allowed to recite janoza. It was said that "so and so" can recite it, and he would come, recite, and in the morning take his silver and go, but there were no mullahs left in the village who could recite janoza. All of the mullahs were cut off, sent away, not allowed. They were exiled. One of them, Mulla Sayid, left, and another disappeared without a trace, and several others fled to make a living; one died here, and another went to Tajikistan to make a living. ${ }^{43}$

Halil's memory of the repression of Islam was more detailed and specific than most accounts, giving the year of the mosque closing, the name of one of the mullahs, the differing fates of several religious leaders, some of whom took action to save themselves, and specifics about how local authorities intervened to stop even small gatherings for prayer.

In several interviews, the interviewer followed remarks about mullahs "leaving" by asking where they went. When he was asked about what mullahs in Xorazm did when the mosques were closed down, Siddiq U. reported: "The mullahs came from all different homelands-Toshkent, Buxoro, Andijon, Namang'on, Samarqand, Chimboy, Qoroqolpoqston, and they all left to return to their homes, leaving behind the madrasa and mosques. Nothing was left." ${ }^{44}$ Otanazar M., from another Xorazm village, had the same understanding. During collectivization, "All of the mullahs were driven out. None were left [...] they went to those places they had come from." 45

The historian Shoshana Keller wrote that OGPU records from 1928 showed urban mullahs trying to escape anti-religious pressures in the city by moving to villages. ${ }^{46}$ Our interviews suggest that rural mullahs also tried moving in order to avoid probable arrest and exile. However, the prevalence of this theme-that the mullahs "left"-raises more questions than it answers. Rural Uzbeks who participated in dispossessing their neighbors often remembered doing so in detail, and with pride. They could name the bois who exploited them, and whom they turned on. They named some of the mullahs who were arrested, but rarely reported names of those who left, or those who stayed, either. Is

\footnotetext{
43) Halil F., b. 1905, Qashqa Daryo 17, transcript 4-5.

44) Sidiq U., Xorazm transcript 3, 4.

45) Otanazar M., b. 1921 Urganch district, Xorazm transcript 2, 5.

46) Keller, To Moscow, Not Mecca, 167-171.
} 
this because those mullahs played a less important role in their lives? Or because the respondents actively participated in dekulakization but did not actively participate in the disappearance of the mullahs? Or were respondents trying to engage in a sort of wishful thinking, assuming that if they did not know precisely what happened to their village mullah and that he possibly "left" rather than was arrested, then there would be nothing to feel guilty about? Did they associate leaving with some sort of ennobling action, such as hijra? Were they deliberately silent about identifying mullahs, because they were told to hide this information? Alternatively, were mullahs really rather unimportant to their lives?

Faizulla R., born in Qashqa Daryo in 1909, was a Party member and a local enforcer of Party policies. He noted that quloqs often tried leaving the village, but that did not mean that they escaped. He said:

During dekulakization, I was a Party representative sent from Samarqand; I went to villages. In the villages, we found them out. We would hold the quloqs, search their properties, and turn them over to the appropriate organization; we would search them, then try them, then make them answerable through imprisonment, and there were instances of seizing their livestock, too. I was not in the court; I wrote up accusations; I was entrusted with that. I would search them out, and then others took care of it. There were occasions when we made mistakes and entered middle dehqons as quloqs, rather than only the rich. Those cases happened. We would arrive in the evening, and if there were quloq who had fled, we would hunt them down. I wasn't NKVD but we went out with them, with the head guard. When they found them [quloqs] they sent them to the appropriate organization. The state sent some into exile; I don't know where-many places. Some of them were exiled and their families went too; in other cases only they were sent and their families stayed. ${ }^{47}$

The question of what happened to mullahs, and how many of them were arrested, shot, or exiled, versus how many of them succeeded at moving, submerging themselves in new circumstances where they could reinvent themselves as workers, and re-emerge later, is an open one. The oral history accounts suggest that rural mullahs met all of these fates. Based on archival documents, Keller proposes that at least 14,000

47) Faizulla Rahmanov, b. 1909, QD 20, 4. NKVD is an acronym for the secret police. 
Muslim religious functionaries disappeared in one way or another from Uzbekistan, but it is difficult to make any definitive statements about how many really were exiled to other parts of the USSR, or were sent to prison camps, or were shot, and how many remained. ${ }^{48}$

In the 1920s and early 1930s, there was a tremendous amount of movement of people in Uzbekistan, from village to city, from village to village, driven by economic need, by a desire for a new life, by a belief that better opportunities lay elsewhere. Some interviewees told very specific stories about family members who moved to the city to escape dekulakization and were successful at re-inventing themselves, while others told of family members who left for Afghanistan. Our interviewees, many of whom would have been quite young when the mullahs disappeared, had some basis for assuming that mullahs, like others from their villages, may indeed have left the village on their own. But the fact that they can name the villagers who were dekulakized, but cannot or do not name the mullahs who disappeared, suggests that they used to talk about these topics in very different ways throughout the Soviet period, and even afterward. In the Soviet period, they actively remembered the dispossessed quloqs, and starting in the 1980s, actively argued over whether they had been rightly or wrongly dekulakized, an argument that expanded, after independence, to include the idea that dispossessing anyone, rich or poor, had been wrong. By contrast, older villagers may have been deliberately silent about who the mullahs were, especially when some of them managed to stay in the village, join the kolkhoz, and continue to practice.

\section{Contesting Practice on the Kolkhoz}

Most of our interview subjects spoke of mosque closures and mullah disappearance as actions taken by others. Never did they implicate themselves in these actions; they tended to attribute them to unnamed Party officials or to the Troikas. However, younger interviewees who were participants in Party youth organizations in the 1930s did remember their own roles in enforcing anti-religious policies. Narzi A.,

48) Keller, To Moscow, Not Mecca, 241. 
the daughter of a poor widow who was grateful for the founding of the kolkhoz, was a Komsomol (Communist Youth League) member in the 1930s, and was one of the enforcers of the anti-religious policies:

There were mosques but they were not open. It was not possible to carry out ceremonies openly. If people got together to perform some customary rite, we Komsomols would prevent it, and would disperse them. Behind our livestock barns there was a cemetery; people would take their sheep or goat there to give it [in sacrifice]; we would find them, find what they were doing, take it away, and then we would slaughter it, go into the mosque, and our own youth gathering would eat it. People did recite janoza [the funeral prayer] then. They were afraid to fast in ruza. ${ }^{49}$

Turdiboi T., born in Namang'on region in 1921, was a Pioneer (Pioneers were a Communist-Party founded organization for younger children) and he too participated in some aspects of enforcing local anti-religious practices:

At school the Pioneers were told [...] whoever has old books at home, you need to tell us. Almost everyone had a Qur'an at home, and then the pioneers would say, "so and so has an old book", and then it would become a matter for the OGPU or the head of the militia. People would come and they would write down what they learned from us young children [...] They took the old books and imprisoned their owners. After a couple of people had been arrested for old books, the rest took theirs and dumped them into the cemetery. There was a little house there where they left them. And then we went secretly and looked at those books - they were beautiful. You would desire them: their bindings were like mirrors, so shiny. We looked through them at all the pictures. The books stayed there. People couldn't bring them home; if they did, they would be arrested..$^{50}$

Although he reported others, and ogled hidden books, Turdiboi also remembered being the recipient of anti-religious surveillance:

School teachers would try to force children to eat during the Ramadan fast. They would come to the homes of those children who were observing the fast, and they came to our home, too. Once it was hayit [eid], the fast was

\footnotetext{
49) Narzi A., b. 1921 QD province, interviewed in Qarshi QD 19, transcript, 7.

50) Turdiboi T., b. 1921, Namang'on 12, 4.
} 
over, and I stayed out of school to play. When they asked why I did not come to school yesterday, I said, because yesterday I want to hayit [i.e., the feast]. Then they came and hit me and said they'd kick me out of school. ${ }^{51}$

Turdiboi's story encompasses the contradictions that were probably daily realities for most Uzbeks: by his actions he supported the state's anti-religious policies, and at the same time felt them as repression.

Oral accounts of elderly Uzbeks who reflected on the 1920s and 1930s sometimes mention the destruction of Islam in their communities, but occasionally also describe how practices continued in the face of severe repression. State repression of religious leadership in rural and urban communities focused primarily on paid religious officials: imams, qazis, domlas, mudarrises and other religious teachers.

There were women religious leaders who held no official positions and who were paid only in gifts from the women whose rituals they led. Because women religious leaders-otin or halfa-were not institutionally connected, and were trained primarily by other women, they were not perceived as important, neither in the pre-Soviet period, nor when religion came under attack. Party members in Uzbekistan derided otins as ignorant, but documents do not show any arrests of women religious leaders for their religious actions. They could be scorned, and there was social pressure on others not to patronize them, but when the Party/State cracked down on Islamic institutions, there was no effort at all to criminalize otins. ${ }^{52}$

Islam is gendered: the roles that men can fulfill differ from those of women. In Central Asia the mosque and maktab were formal, male institutions, while women's practices took place in shrines, or in domestic spaces, led by women who were not officially recognized and were not paid by institutions. Because Muslim men were connected to

51) Turdiboi T., b. 1921, Namang'on 12, 4.

52) On otins, see Kamp, New Woman, chap. 4; Habiba Fathi, "Women of Authority in Central Asian Islam as Identity Preserving References and Agents of Community Restructuring in the Post-Soviet Period", Patterns of Transformation in and Around Uzbekistan, ed. P. Sartori, T. Trevisani (Reggio Emilia: Edizioni Diabasis, 2007), 122-138; Annette Krämer, Geistliche Autorität und islamische Gesellschaft im Wandel: Studien über Frauenälteste (otin und xalfa) im unabhängigen Usbekistan (Berlin: Klaus Schwarz Verlag, 2002). Regional names for women religious teachers include: otin, otin-oyi, otinbuvi, otinbibi, otun, xalfa, xalpa, oy-mullo. 
Islamic institutions, while women were not, the repression of Islam was gendered, and that repression's consequences for the ongoing practice of Islam were also gendered. The otin who was sent into exile, arrested, or shot for her own deeds was a rarity; if she suffered, it was almost always as the family member of a man who fell to repression.

Yo'ldashev, born in Namang'on in 1923, was quoted above noting that there was a domla in his village, but no one went to the mosque; everyone laughed at the idea of public prayer. Personal prayer among younger people was also affected:

After collectivization we did not recite namoz. But my mother was an otinbuvi. She read the old style in Uzbek. But she did not teach me. I studied in Uzbek and Russian school and I did not learn it. But now in Karimov's time, I read it entirely. I learned from my mother. ${ }^{53}$

Yo'ldashev's account suggests that otins remained in their own communities and passed on their knowledge, though only to family members. Saidalixon Hoji M. also learned Islamic practice from his mother, an otin:

My mother was educated old style; she was an otin. She transcribed some of the ayats from the Qur'an into Latin script for my grandmother Farog'at, and I wrote it down. Her father was called Hakim qori, a very educated man from Tashkent, it was said. He had studied [...] And my mother wrote down some of the prayers, and I should have paid more attention. On the front [in WWII], without ablutions, I would recite for my comrades [...] I started saying the five prayers a day from age ten or twelve, so they are fixed in my mind. ${ }^{54}$

Recent studies of otins describe their roles in the late Soviet period and in independence, emphasizing their role as actors in "parallel" or "unofficial" Islam, and their leadership of rituals for adult women. Respondents interviewed for this project presented otins teaching religion to

\footnotetext{
53) Yo’ldashev T., b. 1923 Namang'on region, Nam 1, 23.

54) Saidalixon Hoji M., b. 1921, Marg'ilon 3, 8. "Hoji” indicates that Saidalixon made the Hajj.
} 
young children, though due to the repressive environment, they seem to have limited instruction only to children in their own families. ${ }^{55}$

Village religious leaders also included the people whom Uzbeks referred to as chala mullo, or half-mullahs, men who had learned Islamic practice without much formal education, but who commanded enough respect either for their knowledge or because they belonged to a sacred lineage, that neighbors entrusted them to lead rituals. They received gifts, but were not usually thought of as living primarily on income generated by their religious role. The imam, qazi, and mullah were quite likely to have faced arrest, but the chala mullo faced less difficulty in identifying himself with other poor farmers and could join the kolkhoz.

Mavluda U. and Iboda N., both born in the Farg'ona valley in the early 1920s, talked about how people in their villages were strongly discouraged from practicing Islam, but continued to do so:

M: When we were children, there were five or six of us, and we cared for the livestock, there was no way to do namoz. Now we do it.

I: I don't think anyone even said "bismillah". If the students would say something, I would say, "shut your mouth" [...]

Did they recite namoz on the kolkhoz in the first years?

I: There was fear.

What were they afraid of?

M: No, everyone was afraid and did not recite. Very few people recited [...] People who recited were laughed at. They said those who recite namoz will be taken away, driven out.

I: No one recited, no one knew.

M: They did secretly. My father used to recite secretly. He would not show anyone, he would go over there and recite in peace. No one knew, and he would go pray, and then come back home [...]

I: We used to have one [old] book in our house. I don't remember what happened to it. A great big book like this. It was something that my fatherin-law must have read. They called my father-in-law mullo [mullah]. They would come to him, ask him, he would hang something up, go over there, take it out from under the roof, and hide it back up there. Secretly, so no one saw it. No one-where it was that he hid it at home, or when he took it out to read. He hid it.

55) Fathi, Krämer, and other ethnographers describe otin roles in the late Soviet period until the present. According to my own findings, many otins became Soviet teachers, and the expansion of the school system stripped otins of their traditional teaching tasks, while leaving them with their other roles as ritual leaders to women. Kamp, New Woman, 92f. 
M: People would leave them in cemeteries.

I: Yes, a lot of them were taken to cemeteries and buried there. Back then they did not permit you to recite. ${ }^{56}$

While at first, both women stressed that Islamic practice was thoroughly deterred, they then turned to instances of people in their own families who, as they knew, continued to carry out Islamic practices. Ibodat's father was one of these, but he was not an educated mullah. Those respondents whose fathers or grandfathers had studied in a madrasa took pride in pointing this out. Ibodat described her father-in-law not in terms of formal position and education, but in terms of practice: he recited the prayers and was considered expert enough by others to provide them with some religious leadership, so that they even called him "mullah". Such people provided some of the ongoing ritual leadership to rural communities.

Aliqul I., also from the Namang'on area, gave a different impression than most others of the degree of religious repression. In his words, those on his kolkhoz were not afraid to pray, and did so if they chose to:

We were not very religious. Middling. We would do prayers as it suited us when we were young. There was a mosque and a mullah. Some of them chose to join [the kolkhoz] and those who did not went away to other places. That's how it was, until they all entered. Yes, they [the domlas] were destroyed, they would say, "you are a domla". [On the kolkhoz] we recited namoz. No one prevented it, they let us recite. But then after the Soviet government was built, and the Party and the Komsomol said do not recite, it became rarer. People still prayed openly, the eid prayers. Even though no permission was given, they gathered on their own to recite. The domlas were afraid. Then they were sent away, or arrested, or sent into exile, and they were afraid of being exiled. And then it became official that no one could say anything. But people recited, always. No one forced them not to, or told them not to. ${ }^{57}$

Aliqul's perception that kolkhoz members could pray if they chose to points out that enforcement varied from one community to another. Although some respondents who were children in the 1930s learned

\footnotetext{
56) Mavluda U., b. 1920, and Iboda N., b. 1924, Nam 4, 12.

57) Aliqul I., b. 1916, Namang'on transcript 5.
} 
how to pray from family members, others talked about learning this only after they retired, through some other form of transmission. Tojivoy D.'s comments reflected that were still domlas in his village, but that they were cautious in their own practices:

My grandfather studied in a madrasa. I did not study in the old style. No one taught me, the domlas were afraid of me. I said, I've never had anyone arrested or quarreled with anyone, everyone likes me. But they were afraid and did not teach me. Now, thanks to God, I recite the 5 daily prayers $[\ldots]$ I learned how to do the prayers from books. I did not learn it from my grandfather; as he died when I was young..$^{58}$

Although it seems clear that certain Islamic practices, especially recitation of funeral prayers, were constantly present in the villages, these accounts also confirm that Soviet anti-religious pressure made villages either desist from many normal Islamic practices out of fear or lack of means (no mosques, no mullahs), or people hid those practices so thoroughly that only their own family members would know.

\section{Conclusion}

Oral histories with elderly collective farmers in Uzbekistan who recalled the establishment of their collective farms in the 1930s, depicted the closing of village mosques and the disappearance of many rural mullahs. Government policies were focused on eradicating Islamic institutions, and those who lived in villages remembered the multiple ways by which anti-religious policies were enforced. Mullahs were arrested at night, or exiled as targets of dekulakization. But many mullahs left villages, and may have succeeded at hiding their identity by moving to places where they were not known, or where their kin protected them. The sweep was not total: mullahs remained in many villages, though they may have earned their living by working on the collective farm. In addition, those religious leaders who had never been closely tied to Islamic institutions, such as otins, were not targeted for arrest or removal. Our respondents remembered times when it was difficult to engage in any practice of Islam publicly, but they emphasized that nonetheless, com-

58) Tojivoy D., b. 1917 Parkent, Tashkent 2, 9. 
munity members fulfilled the ritual that they deemed most essential: the funeral prayer.

This collection of oral history interviews provides some evidence about the practice and repression of Islam in rural Uzbek communities in the interwar period. The topic of these interviews was not religious practice, but rather collectivization, so many of the accounts that respondents gave about mullahs, mosques, and prayers, were incidentally mentioned, not systematically sought out. Oral histories recorded many decades after the events they portray cannot claim the reliability that contemporary documents have. Memories change through the passage of time, and in response to new discourses. The different political currents and collective discourses that shape individual tellings of stories can be seen in the ways that respondents remembered dekulakization. They assigned to the category quloq those who were described as "oppressors" by Communist Party discourse, as it was used in the 1930s, but they also debated whether certain dehqons had been "wrongly" dekulakized, following discourses of the 1960s and 1980s.

However, respondents from communities scattered across Uzbekistan told similar stories not only because political discourse shaped their memories, but because they lived through common experiences during the period of collectivization. The Soviet state's efforts to repress religious practices took the same form throughout Central Asia, and the results varied in severity and effectiveness, but were repeated in village after village across Uzbekistan. Members of collective farms had shared participation in driving out quloqs, whose names they recounted through the years as they told of their kolkhoz's formation. In cases where those dispossessed quloqs were also mullahs, they recalled and repeated their names. Communities also shared in silences: time and again, those who reported that some mullahs stayed and continued to lead the prayers did not name them, and those who told stories of mullahs who left did not name them either. This suggests that the survival of Muslim leaders in communities was linked to the community's agreement to conceal their presence and activities. These oral history accounts, through their commonalities, attest that most communities found some limited ways to continue ordinary Islamic religious practices even after the state destroyed most of Islam's public institutions. 
Copyright of Welt des Islams is the property of Brill Academic Publishers and its content may not be copied or emailed to multiple sites or posted to a listserv without the copyright holder's express written permission.

However, users may print, download, or email articles for individual use. 